at University College, Swansea. Much of his work relates to the carboniferous limestone of South Wales, where he has mapped extensive areas and revealed structural information of great interest in relation to the folding of the limestones. In connexion with these studies he has investigated carboniferous fossils, and especially the brachiopods and goniatites. He has made considerable contributions to the geomorphology of Wales, and his studies of river development have been of great interest. Work on glacial deposits, on raised-beach and cave deposits, and on more general geological problems indicates the wide range of his interests. Prof. George has also been active in university administration and in various branches of adult educational work.

\section{Chemistry at Birmingham}

A SECOND chair has been established in the Department of Chemistry in the University of Birminghy and Dr. Maurice Stacey, at present reader $\mathrm{j}$ biological chemistry, has been appointed to it. Dr. Stacey graduated at Birmingham in 1929/and engaged in carbohydrate research work unger Prof. W. N. Haworth. He obtained his Ph.D. degree in 1932 and in the following year was awarded the Meldola Medal mainly for his work with Haworth and Hirst on the synthesis of vitamin C. In the same year he gained a Beit Memorial fellowship for medical research, which he held at the London School of Hygiene and Tropical Medicine under Prof. $\mathbf{H}$. Raistrick. Here he worked on the structure of complex carbohydrates produced by moulds and on the immunochemistry of bacteria in the typhoid group. In 1936 he rejoined Prof. W. N. Haworth's staff at Birmingham as lecturer and in 1937 spent some time with Prof. M. Heidelberger at Columbia University Medical School, New York. He was awarded his D.Sc. in 1939. For some years Dr. Stacey has directed a team of research workers engaged in studying the chemistry of micro-organisms and recently has made important advances in this field. Since 1940 he has been leader of Prof. W. N. Haworth's large group engaged in problems connected with the chemical side of the atomic energy project. Dr. Stacey was a member of the Tube Alloys Chemical and other Panels and is a member of council of the Chemical Society and a fellow of the Royal Institute of Chemistry.

Dr. Fred Smith, who is returning to the department in October after spending two and a half years on the atomic energy project and at the University of Minnesota, has been promoted to a senior lectureship in the University. Dr. E. J. Bourne has been appointed to a lectureship. Dr. M. Webb has been appointed to an Imperial Chemical Industries fellowship. Dr. F. H. Newth and Mr. P. W. Kent have been appointed assistant lecturers. Mr. J. Read and Dr. G. A. Gilbert, Imperial Chemical Industries fellows, are shortly going to the United States to engage in research work.

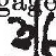

European Archæolpgy at Oxford : C. F. C. Hawkes

Mr. Christoper F. C. Hawkes, the first holder of the nyw has European archæology at Oxford, is one of th $t$ active among the younger prehistorians. H was a scholar of Winchester and of Ney College, and entered the British Museum shortly aftertaking his degree in the Honour Sehool of Litere Humaniores. While still an undergraduate, he took part in the excavation of the entrenched camp on St. Catharine's Hill, and later conducted a series of excavations at Colchester (Roman Camulodunum), the results of which have been published recently. In 1932 he was a secretary of the International Congress of Prehistoric and Protohistoric Sciences in London, and published with W. T. D. Kendrick a retrospect of "Archæology in England and Wales, 1914-1931". Mr. Hawkes is a fellow of the Society of Antiquaries and an active member of the Royal Anthropological Institute and the Archæological Institute. His principal publication is "The Prehistoric Foundations of Europe" (Methuen, 1940). In his excavations and other field work, Mr. Hawkes has shown himself an inspiring leader and teacher, and at Oxford he will have every encouragement to build up a strong school of prehistoric archæology.

\section{Presentation to Prof. E. K. Rideal, F.R.S.}

IT was announced in Nature for December 25, 1945, that Prof. E. K. Rideal, professor of colloid science in the Undversity of Cambridge, had been appointed Fullerign Professor at the Royal Institution and director of the Davy Faraday Laboratory as from nex October. Recently the Department of Colloid Solence issued invitations to all its members past and fresent, and to all those who had been associated with Prof. Rideal as collaborators in research, to a presentation dinner. This took place in Trinity Hall, Cambridge, on July 6, and nearly ninety people attended from all over the British Isles as well as a few from overseas. To mark this occasion a bibliography was prepared of all the original scientific works achieved under Prof. Rideal's direction or in association with him over a period of somethirty-five years. A copy was presented to Prof. Rideal and to all subscribing members. The book has some five hundred and fifty references of original work, and emphasizes Prof. Rideal's great activity in building up the School of Colloid Science in the University of Cambridge. We feel sure that the cordial good wishes of many who were unable to attend this function will go with Prof. Rideal in his new appointment.

\section{Commemoration ol Alexander Samoilov $\mathrm{H}$ \\ A CONFERENCl dedicated to the memory of the} eminent pha logist Prof. Alexander Samoilov took place repuly in the University of Moscow on the occasion. If the fifteenth anniversary of his death in 1939 - Prof. Samoilov, who was responsible for infotiant advances in the physiology of the nervous syslem and in electrocardiography, was well known outside his country-in the United States, Great Britain and Holland, where he delivered speeches and lectures many times. Papers sent by E. D. Adrian (Cambridge), John F. Fulton (Yale) and Paul D. White (Boston, Mass.) were read at the conference. Speeches were also delivered by Ch. S. Koschtojanz, director of the Samoilov Laboratory of the University of Moscow and professor of physiology, and by Prof. V. Parin. The Institute of History of Natural Sciences of the Academy of Sciences of the U.S.S.R. organised in connexion with the conference an interesting exhibition of photographs portraying the life and works of Samoilov and his friendly and scientific relations with many celebrated physiologists of Europe and America. The Institute presented to each participant at the conference a reprint of the bibliography of the works of Prof. Samoilov. 